\title{
Mathematical physics e-module: A study of students' perception based on gender
}

\author{
Astalini Astalini a, Darmaji Darmaji b , Dwi Agus Kurniawan c*, Nadia Natalia Simamora ${ }^{\text {d }}$ \\ Universitas Jambi. Jl. Jambi Muara Bulian, Mendalo Darat, Muaro Jambi, Jambi 36361, Indonesia \\ a astalinizakir@unja.ac.id; bdarmaji@unja.ac.id; cdwiagus.k@unja.ac.id; d nadianataliaa12@gmail.com \\ * Corresponding Author.
}

Received: 5 May 2021; Revised: 24 July 2021; Accepted: 28 July 2021

\begin{abstract}
Student's perception is the student's assessment of something or information. The objective of this study was to discover how students' general perceptions and gender differences in electronic modules of mathematical physics. The research type is surveybased research with quantitative approach. The research population consists of physics education students from Universitas Jambi with the sample of 80 students from class A and class B. The data analysis techniques used in the study are descriptive statistics analysis and inferential data analysis using t-tests. The results showed that, overall, students have a positive perception with a Sig. (2-tailed) value of $0.011<0.005$, which means that there is a significant difference in students' perception. The perception of class A students with gender differences has a Sig. (2-tailed) value of 0.003 , while the grade B students have a Sig. ( 2 tailed) values of 0.020 and 0.013 . This means that class $A$ and classs $B$ students have a discernible difference of perception. Student's perception may be used as a determining factor in the choice of learning materials. This research can be used as a guideline for the development of student perception assessment in the electronic module of Mathematical Physics in the future. The update of this study aims to compare students' perceptions of the overall online module of mathematics and gender differences.

Keywords: E-module; Gender; Mathematical Physics; Perception
\end{abstract}

How to Cite: Astalini, A., Darmaji, D., Kurniawan, D. A., \& Simamora, N. N. (2021). Mathematical physics e-module: A study of students' perception based on gender.Momentum: Physics Education Journal, 5(2), 209-226. https://doi.org/10.21067/mpej.v5i2.5602

\section{Introduction}

The development of era increases technology and science. The development of science and technology creates a sense that the world is limitless (Sopacua et al., 2020). Technology, such as digital tablet, is critical to assisting students in learning (Billman et al., 2018; Ibrahim et al., 2016). The rapid development of technology requires the realization of technology using smart internet or mobile internet as technological progress (Dalkilic et al., 2017; Stojanović et al., 2020; J. Xu et al., 2018). Therefore, technological development has an important role in education.

Education is capable of improving its abilities by utilizing technological developments. Education in Indonesia is required to prioritize meaningful learning processes adapted to $21^{\text {st }}$ century learning models to address the era of competition (Siswono, 2017; Tristanti \& Hidayati, 2020). In the $21^{\text {st }}$ century, the main goal of science education is to develop critical thinking skill as an essential skill (Holmes et al., 2017; Prani et al., 2018; Tiruneh et al., 2016, 2017). By combining education and technology, it is revealed that education has no impact compared to education that is paired on technology, so that technology is used as a means of motivating individuals (Bice et al., 2019; Rote, 2017). To monitor the development of technology in today's digital era 4.0, interesting learning media are needed to be accepted by students (Purnami et al., 2020), so that learning will be easily understood. 
There are many tools used in the teaching and learning process, including learning media. Learning media used is usually in the form of audio, video, and e-text. Some learning media that are often explored include slides, hypermedia, etc (Ge, 2021; Mcnamara \& Shapiro, 2015; Park et al., 2015; H.-F. Shang, 2017; Stebner et al., 2017). The use of learning media in electronic form that does not only contain subject matter can help the learning process become more effective and efficient to improve students' abilities (Qi, 2018; Asrowi et al., 2019; Williamson et al., 2019; Septiani et al., 2020). In using learning media, smart media tools are needed to record in the form of still images, video, and audio. One of which is animation media, which can be used by students without having to experience firsthand what they should learn (Leinonen et al., 2016; Vartiainen et al., 2019). In addition to animation media, there are also other media that may be used in the learning, namely modules.

Modules are teaching materials that contain materials, methods, and evaluations that are systematically designed for students to better understand the material by introducing the key concepts (Barr \& Jackson, 2018; Sopacua et al., 2020; Wati et al., 2020). This module is designed by the author to make it easier for students in the learning process by helping students understand the concept of learning materials (Fortner et al., 2016; Ping \& Osman, 2019; Asrial et al., 2020; Chongo et al., 2021). Modules can be in the form of print modules and electronic modules which are often referred to as e-modules. E-module is a computer technology-based module that contains a review of learning materials followed by questions to make it easier for users to understand the material. Emodules can also display images, audio, video and animation, as well as formative tests or quizzes. (Li et al., 2016; Patel et al., 2018; Sofyan et al., 2019; Rahmat et al., 2020). One of the courses which utilizes modules is mathematical physics.

Mathematical Physics combines physics to mathematics. Mathematics is the essence of education that crosses all sciences (Oyedeji, 2017; Laurens et al., 2018; Suryanti, 2021), while physics is a part of science that is closely related to how to systematically analyze natural phenomena and apply understanding concepts in the learning (Berek et al., 2016; Gunawan et al., 2019; Wartono et al., 2018). Mathematical physics as a subject has the aim that students have the ability to formulate various physical processes into mathematical statements. The supporting source used in mathematics physics lessons is an English book entitled Mathematical Methods in the Physical Sciences by Mary L. Boas. However, the use of Indonesian and the use of some translated foreign terms are still difficult for students to understand. Therefore, additional media is needed to make it easier for students to understand the material in mathematical physics. One solution for students in mastering the material is to use e-modules that can help in learning the subject matter independently, as well as a source that provides new learning experiences. (Abuhassna \& Yahaya, 2018 Torbjörnsson et al., 2018; Ng, 2019; Asrial et al., 2020; Darmaji et al., 2020). E-modules can increase the effectiveness and flexibility of learning, increase learning motivation and learning outcomes, and make learning more interesting and not boring because it is equipped with pictures, audio and video. In addition, it is also durable and more practical to carry everywhere (Yasa et al., 2018; Ningtyas et al., 2019; Rahmatika et al., 2020). To see if e-module can help students to understand the material of mathematical physics, it takes the perception of students.

Students' perception of media that is able to provide information correctly between the sender and recipient of information is that the media can help them in learning activities and can motivate them to follow the learning process, so they get a learning experience (Limatahu et al., 2017; Darmaji et al., 2019). Perception is an individual process in receiving sensory impressions on science, honesty, courage, assertiveness, courage to compete, hard work, and perseverance about media concepts (Kim et al., 2019; Rusydiyah et al., 2020). The part of the process of sending messages or information into the human brain related to the important but not ideal senses of sight, hearing, touch, taste and smell is also called perception (Asrial et al., 2020; Darmaji et al., 2020). Positive perception is an individual's assessment of an object or information with a positive view or in accordance with the expectations of the perceived object. While the individual's views that are contrary to the expectations of the perceived object or the rules applied are called negative perceptions. (Darmaji et al., 2020). Varied perceptions of students are expected to show an increase 
in better knowledge and ease of learning so that it can be considered as positive perceptions (Dessie \& Sewagegn, 2019; Leeniva, 2019; Syauqi et al., 2020). A person's perception can be influenced by gender, which affects differences in roles, functions, positions, responsibilities and behavioral rights of a person which are broadly related to one another (Dharma, 2016). Gender can be a factor that influences the learning process and the achievement of learning outcomes (Liu \& Young, 2017; Bhagat \& Chang, 2018; Chiu, 2018; Suyatna et al., 2018; Fitriani et al., 2019). Based on gender, it can be seen that there is a positive perception that shows that e-modules can help students understand mathematics and physics material for males and females.

This research was conducted to complement the prior research. One of which is the research conducted by Darmaji, Kurniawan, Astalini, et al. (2019) regarding student perceptions of the electronics module in physics practicum. Furthermore, research conducted by Darmaji, Kurniawan, \& Irdianti (2019) on the use of e-modules in basic physics practicum with research results stating that students' perceptions of using e-modules are in the high category, meaning that the use of emodules is more interesting in doing basic physics practicum. Then, the results of the research conducted by Darmaji, Kurniawan, Astalini, Winda, et al (2020) on student perceptions of the use of e-modules in the Melde experimental practicum showed that students have positive perceptions, thus students can develop the basic science process skills.

Based on existing research conducted by previous researchers, there has been no research on student perceptions of e-modules in mathematical physics course and no research has conducted research on student perceptions based on gender differences. Therefore, researchers conducted a study to examine student perceptions of the mathematical physics e-module based on gender differrences in order to complete the shortcomings of previous research.

Given the importance of students' perceptions of e-modules, the researchers conducted this study with the aim of knowing students' perceptions of the mathematical physics e-module and to determine student perceptions based on gender differences in the mathematical physics e-module.

\section{Method}

The type of instrument used is a survey. This study uses a quantitative approach that is used to conduct research on a particular population or sample with data collection and analysis instruments or statistical data based on the study of the philosophy of positivism (Cohen et al., 2007; Darmaji et al., 2019). Quantitative research sees the world as an objective reality to be studied with a positive paradigm, where data such as questionnaires are analyzed (Hodis et al., 2016; Koutiva et al., 2016). Quantitative research focuses on object analysis to display the size of variables and conclusions that can be measured in a sample of a population (Hammer \& Habib, 2016; Pastore, 2017; Akar \& Çelik, 2019). Quantitative research is conducted to investigate causal hypotheses by comparing one or more groups with a comparison group to see differences (Wang \& Chang, 2018; Alkhateeb \& Milhem, 2020; Darmaji et al., 2020). This study aims to see the difference in students' perception of e-modules in class $A$ and lass $B$, and also aims to see the difference in students' perception of e-modules based on gender in class $A$ and class $B$.

The population of this study is physical education students class 2019 Jambi University, where the population is a collection of different non-consecutive units in the sample paired with the appropriate value of the desired variable, although most of the sample units cannot provide meaningful information for the population. (Vincent \& Thompson, 2017; Qureshi et al., 2018). The sample used in this study were all 80 physics students consisting of 40 students for class $A$ and 40 students for class B. The sampling method needs to be determined (Simpson \& Lord, 2015). As the number of samples matches the number of populations, the sampling strategy is correct (Sumual \& Ali, 2017). The sample used in this study was selected using a simple random sampling technique, which is the simplest technique in selecting samples to obtain the optimal number of samples. (Singh, 2003). This study used simple random sampling because the research sample was determined by considering the use of PCs or cellphones in learning. A PC or cellphone is used to access material in the mathematical physics e-module. 
This research data comes from quantitative data obtained through questionnaires (West, 2015; Rintakorpi \& Reunamo, 2017; Tölle et al., 2019). The questionnaire used in this study was a student perception questionnaire with 15 statements. Data collection is done by distributing questionnaires using Google Form to students. The reason for using a questionnaire is because it can easily collect and measure all information from the research sample using a rating rating scale (Elmendorf \& Song, 2015; Lupi et al., 2017). The questionnaire used in this study was made using a Likert scale to measure perception with statements that focus on a person's perspective on something (Wu \& Leung, 2017; Caia et al., 2018; Ikeda et al., 2018). Questionnaires given to students have different scores, namely Strongly Agree $(S A)=4$, Agree $(A)=3$, Disagree $(D)=2$, and Strongly Disagree $(S D)=1$. Perception questionnaire criteria can be seen in Table 1.

Table 1. Student Perception Criteria

\begin{tabular}{cc}
\hline Range & Criteria \\
\hline $15,00-26,25$ & Very bad \\
$26,26-37,50$ & Bad \\
$37,51-48,75$ & Good \\
$48,76-60,00$ & Very good \\
\hline
\end{tabular}

The data analysis technique in this study used descriptive statistical analysis and inferential statistics. Descriptive statistics are used to analyze and present the data that has been obtained from the calculation of the mean, median, mode, maximum score, and minimum score (Shang, 2015; Carolina et al., 2016; Río \& Fernández, 2016), and Inferential statistics are used to test hypotheses consisting of prerequisite testing, namely normality test and homogeneity test, then followed by hypothesis testing (t-test) with a significance level of $5 \%$, then the test results will be compared with $t_{\text {tabel, }}$ (Lestari \& Parmiti, 2020). The flow chart in this study can be seen in Figure 1.

\begin{tabular}{|l|}
\hline - Formulating Problems \\
\hline - Basic Theory Review \\
\hline -Spread the Perception Questionnaire \\
\hline -Data collection \\
\hline -Data Analysis (descriptive statistics and inferential statistics) \\
\hline -Conclusion \\
\hline
\end{tabular}

Figure 1. Research flow chart

\section{Results and Discussion}

Mathematics Physics is one of the most important subjects in physics education which is the mother of all sciences and the basis of all research to understand the patterns of the world (Yalçın, 2017; Hu et al., 2018; Rezeki et al., 2021). And physics is a part of science that is closely related to how to systematically analyze natural phenomena and apply conceptual understanding in the learning (Berek et al., 2016; Wartono et al., 2018; Gunawan et al., 2019). In analyzing natural phenomena systematically, mathematics is needed as a basis. Mathematics and physics are 2 subjects that belong to a single unit of knowledge, namely science. So that in physics education the two subjects are concurrently into one subject, namely the mathematical physics course.

This study was conducted to see students' perceptions of the e-module used as a medium in mathematics physics courses. The data was obtained from the distribution of student perception research questionnaires to 80 physics education students at the University of Jambi. The results of the analysis of research data are used as guidelines for developing student perception assessments in the mathematics physics e-module in the future. The novelty in this study is to compare students' 
perceptions with gender differences. Gender was chosen because it is one of the factors that distinguishes each individual's perception and is a structured social construction that refers to individual identity (Xiao \& Hong, 2017; Holliday et al., 2019).

\section{Perception of Class A and Class B Students on Mathematical Physics E-Module}

The results of descriptive statistical data analysis on the perception of class A students on the mathematical physics e-module using SPSS 22 can be seen in Table 2.

Table 2. Description of perceptions of class A students

\begin{tabular}{|c|c|c|c|c|c|c|}
\hline \multicolumn{2}{|c|}{ Classsification } & \multirow{2}{*}{ Total } & \multirow{2}{*}{$\%$} & \multirow{2}{*}{ Mean } & \multirow{2}{*}{ Min } & \multirow{2}{*}{ Max } \\
\hline Range & Criteria & & & & & \\
\hline $15,00-26,25$ & Very bad & 0 & 0 & \multirow{4}{*}{42,42} & \multirow{4}{*}{33} & \multirow{4}{*}{55} \\
\hline $26,26-37,50$ & Bad & 7 & 17,5 & & & \\
\hline $37,51-48,75$ & Good & 28 & 75 & & & \\
\hline $48,76-60,00$ & Very good & 5 & 7,5 & & & \\
\hline
\end{tabular}

Based on Table 2, class A students showed perceptions of the mathematical physics e-module with very bad criteria about $0 \%$, bad criteria of $17.5 \%$ ( 7 out of 40 students), good criteria of $75 \%$ ( 28 out of 40 students), and very good criteria of $7.5 \%$ ( 5 out of 40 students). Meanwhile, based on the perception scale, the data obtained is an average score of 42.42 with a minimum score of 33 and a maximum score of 55 . These results indicate that the perception of class $A$ students towards the mathematical physics e-module has a positive category and is in good criteria.

The results of analysis of descriptive statistics on perception of grade B students on the mathematical physics e-module using SPSS 22 can be seen in Table 3.

Table 3. Description of perceptions of class B students

\begin{tabular}{ccccccc}
\hline \multicolumn{2}{c}{ Classification } & Total & $\%$ & Mean & Min & Max \\
\hline Range & Criteria & & & & \\
$15,00-26,25$ & Very bad & & 0 & 0 & 30 & 55 \\
$26,26-37,50$ & Bad & 17 & 42,5 & 39,4 & & \\
$37,51-48,75$ & Good & 20 & 50 & & \\
$48,76-60,00$ & Very good & 3 & 7,5 & & \\
\hline
\end{tabular}

Based on Table 3, class B students showed perceptions on the mathematical physics e-module with very bad criteria about $0 \%$, bad criteria of $42.5 \%$ (17 out of 40 students), good criteria of $50 \%$ ( 20 out of 40 students), and very good criteria of $7.5 \%$ ( 3 out of 40 students). Meanwhile, based on the perception scale, the data obtained is an average score of 39.4 with a minimum score of 30 and a maximum score of 55 . These results indicate that the perception of class $B$ students towards the mathematical physics e-module has a positive category and is in good criteria.

After conducting descriptive statistic analysis, the inferential analysis is done, namely $t$ test. But before conducting the $t$ test, normality test and homogeneity test are conducted to see if the research data is normal and homogeneous. The results of normality test data using SPSS 22 can be seen in Table 4.

Table 4. SPSS Output Normality Test Results

\begin{tabular}{|c|c|c|}
\hline \multicolumn{2}{|r|}{ Classification } & \multirow{2}{*}{$\begin{array}{c}\text { Total } \\
40\end{array}$} \\
\hline $\mathrm{N}$ & \multirow{6}{*}{ Std. Deviation } & \\
\hline Normal Parameters & & ,00 \\
\hline & & 5,1079965 \\
\hline Most Extreme & & ,094 \\
\hline \multirow[t]{2}{*}{ Difderences } & & ,094 \\
\hline & &,- 067 \\
\hline \multicolumn{2}{|c|}{ Kolmogrov-Smimove Z } & ,094 \\
\hline \multicolumn{2}{|l|}{ Asymp. Sig. (2-tailed) } & ,200 \\
\hline
\end{tabular}

Test distribution is normal 
From Table 4, the output of the SPSS normality test is K-S Z $=0.094$ with $p=0.200(p>0.05)$. This means that the data is normally distributed. Furthermore, after the data were normally distributed, homogeneity test was conducted to determine whether several population variants were the same or not. This test is carried out as a prerequisite in conducting the $t$ test. The results of the homogeneity test using SPSS 22 can be seen in Table 5.

Table 5. SPSS Output Homogeneity Test Results

\begin{tabular}{cccc}
\hline Levene Statistic & $\mathrm{df}_{1}$ & $\mathrm{df}_{2}$ & Sig. \\
\hline .653 & 1 &, 63 &, 422 \\
\hline
\end{tabular}

From Table 5 obtained the output result of SPSS homogeneity test i.e. sig value. 0.422 which means $p>0.05$ equals $0.422>0.05$, so the variants of the two population groups (class A and class B) in this study are the same (homogeneous). Once it is known that the data is normal and homogeneous, the t-test is carried out. The results of the t-test using SPSS 22 can be seen in Table 6 .

Table 6. Results of the SPSS t-test Output

\begin{tabular}{|c|c|c|c|}
\hline Group & $\mathrm{N}$ & Sig. & Sig. (2 tailed) \\
\hline Class A & 40 & & , 011 \\
\hline Class B & 40 & ו / , & ,011 \\
\hline
\end{tabular}

From Table 6 obtained SPSS output result the t-test i.e. sig value 0.757 . This means a sig value $0.757>0.05$ which indicates that the data variance between class $A$ and class $B$ is homogeneous or equal. Then, also obtained the value of Sig. ( 2 tailed) of 0.011 . This means the value of Sig. ( 2 tailed) 0.0110 .05 which means that $\mathrm{HO}$ is rejected and $\mathrm{Ha}$ is accepted. Thus, there is a noticeable difference between the perception of grade $A$ and grade $B$ students in the mathematical physics e-module.

Based on descriptive statistical analysis in class $A$ and class $B$, the results show that $75 \%$ (28 of 40) students of class $A$ are in good criteria and 50\% (20 out of 40 ) students of class $B$ are in good criteria. That is, students of class $A$ and class $B$ have a positive perception of the use of electronic modules in mathematical physics subject. Based on the inferential analysis, it was found that the data from the normality and homogeneity test results, as well as the t-test results in class A and class B showed the value of Sig. ( 2 tailed) 0.0110 .05 which means $\mathrm{HO}$ is rejected and $\mathrm{Ha}$ is accepted. The results of statistical analysis show that most students already have a positive perception in the use of e-modules. However, based on the results of the study, there are still students who have perceptions that are not good enough in using e-modules in learning mathematical physics, namely $17.5 \%$ ( 7 of 40) students of class A and $42.5 \%$ (17 of 40 ) students of class B. It can be seen that the majority of students in class $A$ have a more positive perception of the mathematical physics e-module than class $B$ because in class $B$, the perception of students with bad criteria is almost comparable to the perception of students with good criteria. The results of statistical analysis are reinforced by the results of inferential analysis, namely the t-test which shows that there is a striking difference between the perceptions of class $A$ and class $B$ students on the mathematical physics e-module. However, the results are in line with the statement that electronic modules can help students understand mathematical physics materials more easily because e-modules are equipped with images, video and audio and also more durable and practical to carry around (Ningtyas et al., 2019; Rahmatika et al., 2020). E-modules are used in line with the development of technology, where in the learning process use electronic-based learning media so that students can understand concepts and processes without having to do it directly. Learning media is applied not only to the understanding of concepts, but also to the process of physics (Darmaji, Kurniawan, Astalini, et al., 2019; Darmaji, Kurniawan, Astalini, Winda, et al., 2020).

\section{Perception of Female and Male Students in Class A on Mathematical Physics E-module}

The results of analysis of descriptive statistics on perception of female students of grade A in emodule of mathematical physics using SPSS 22 can be seen in Table 7. 
Momentum: Physics Education Journal, 5 (2), 2021, 215

Astalini Astalini, Darmaji Darmaji, Dwi Agus Kurniawan, Nadia Natalia Simamora

Table 7. Description of the perceptions of female students in class $A$

\begin{tabular}{ccccccc}
\hline \multicolumn{2}{c}{ Classification } & Total & $\%$ & Mean & Min & Max \\
\hline Range & Criteria & & & & \\
$26,00-26,25$ & Very bad & & 0 & 0 & & 48 \\
$37,51-48,50$ & Bad & 6 & 27,3 & 40,27 & & \\
$48,76-60,00$ & Good & 16 & 72,7 & & \\
\hline
\end{tabular}

Based on Table 7, female students of class A showed perceptions on the mathematical physics e-module with very bad criteria about $0 \%$, bad criteria of $27.3 \%$ ( 7 out of 22 students), good criteria of $72.7 \%$ ( 16 out of 22 students), and very good criteria of $0 \%$. Meanwhile, based on the perception scale, the data obtained is a mean score of 40.27 with a minimum score of 33 and a maximum score of 48. These results indicate that the perception of female students of class $A$ towards the mathematical physics e-module has a positive category and is in good criteria.

The results of analysis of descriptive statistics on perception of male students of class $A$ towards mathematical physics e-module using SPSS 22 can be seen in Table 8.

Table 8. Description of the perceptions of male students in class $A$

\begin{tabular}{ccccccc}
\hline \multicolumn{2}{c}{ Classification } & Total & $\%$ & Mean & Min & Max \\
\hline Range & Criteria & Very bad & 0 & 0 & & \\
$15,00-26,25$ & Bad & 0 & 0 & 45,05 & 37 & 55 \\
$37,26-37,50$ & Good & 13 & 58,8 & & \\
$48,76-60,75$ & Very good & 5 & 22,5 & & \\
\hline
\end{tabular}

Based on Table 8, male students of class A showed perceptions on the mathematical physics emodule with very bad and bad criteria about $0 \%$, good criteria of $58.8 \%$ ( 13 out of 18 students), and very good criteria of $22.5 \%$ ( 5 out of 18 students). Meanwhile, based on the perception scale, the data obtained is a mean score of 45.05 with a minimum score of 37 and a maximum score of 55 . These results indicate that the perception of female students of class $A$ towards the mathematical physics e-module has a positive category and is in good criteria.

After the descriptive statistical analysis was carried out, then the inferential analysis was carried out, namely the t-test. However, before conducting the t-test, a normality test and homogeneity test were carried out to see whether the research data were normal and homogeneous. The results of the data normality test using SPSS 22 can be seen in Table 9.

Table 9. SPSS Output Normality Test Results

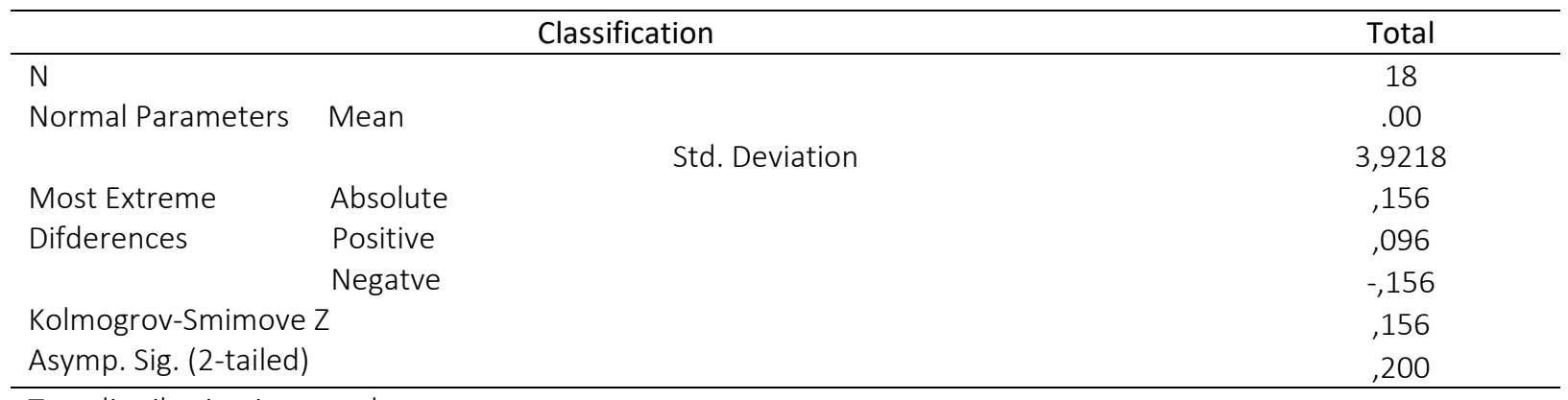

Test distribution is normal

From Table 9, the output of the SPSS normality test is K-S Z $=0.156$ with $p=0.200(p>0.05)$, which means the data is normally distributed. Furthermore, after the data is normally distributed, homogeneity test was carried out to find out whether there are similarities in several population variants. This test was carried out as a prerequisite in conducting the t-test. The results of the homogeneity test using SPSS 22 can be seen in Table 10. 
Momentum: Physics Education Journal, 5 (2), 2021, 216

Astalini Astalini, Darmaji Darmaji, Dwi Agus Kurniawan, Nadia Natalia Simamora

Table 10. SPSS Output Homogeneity Test Results

\begin{tabular}{cccc}
\hline Levene Statistic & $\mathrm{df}_{1}$ & $\mathrm{df}_{2}$ & Sig. \\
\hline, 977 & 1 & 38 &, 329 \\
\hline
\end{tabular}

From Table 10, the output of the SPSS homogeneity test is the sig value. 0.329 which means $p$ $>0.05$ is equal to $0.329>0.05$, so the variance of the two population groups (male and female) in this study is homogeneous. After knowing that the data is normally distributed and homogeneous, then the t-test was carried out. The results of the t-test using SPSS 22 can be seen in Table 11.

Table 11. Results of the SPSS t-test Output

\begin{tabular}{|c|c|c|c|}
\hline Group & $\mathrm{N}$ & Sig. & Sig. (2 tailed) \\
\hline Female & 22 & 616 & ,003 \\
\hline Male & 18 & 616, & ,003 \\
\hline
\end{tabular}

From Table 11, the results of the SPSS t-test output are obtained, namely the value of sig. 0.616 which means the value of sig. $0.616>0.05$ indicates that the data variance between female and male students in class A is homogeneous. Then, obtained the value of Sig. ( 2 tailed) of 0.003 which means the value of Sig. ( 2 tailed) $0.0>0.05$ indicates that $\mathrm{HO}$ is rejected and $\mathrm{Ha}$ is accepted. Thus, there is a striking difference between the perceptions of female and male students in class $\mathrm{A}$ on the mathematical physics e-module.

Based on the results of descriptive statistical analysis on female and male students of class $A$ in the study, it showed that $72.7 \%$ ( 16 of 22 ) female students in class A were in good criteria and $58.8 \%$ (13 of 18) male students in class A were in on good criteria. This means that the male and female students in class $A$ have a positive perception of the use of electronic modules in mathematics physics classes. Based on the inferential analysis, it was found that the data of normal and homogeneous learning outcomes and the results of the t-test on female and male students of class A showed sig. (2 tailed) of 0.003 which means the value of Sig. ( 2 tailed) $0.003<0.05$ indicates that $\mathrm{HO}$ is rejected and $\mathrm{Ha}$ is accepted. The results of statistical analysis showed that most of the female and male students had positive perceptions in the use of e-modules, but there were also students who had very good perceptions of the criteria for using e-modules in mathematical physics subject.

The results of the statistical analysis are reinforced by the results of inferential analysis, namely the t-test which shows that there is a striking difference between the perceptions of female and male students of class A on the mathematical physics e-module. There are also gender differences in the class. Based on the results of the study, male students had better descriptive statistical analysis than female students as indicated by the average score and also the percentage of the number of students.

In fact, female or male students must have the ability to use electronic modules to more easily understand learning materials and keep up with technological developments. In its development, education uses technology as a medium of learning to make it easier to understand the existing learning materials. One of the digital learning media used by students to understand the subject matter independently is e-module (Asrial et al., 2020; Darmaji, Kurniawan, Astalini, Winda, et al., 2020).

Perception of Female and Male Students in Class B on Mathematical Physics E-module

The results of descriptive statistical analysis on the perception of female students in class $B$ towards the mathematical physics e-module using SPSS 22 can be seen in Table 12.

Table 12. Description of the perceptions of female students in class B

\begin{tabular}{|c|c|c|c|c|c|c|}
\hline \multicolumn{2}{|c|}{ Classification } & \multirow{2}{*}{ Total } & \multirow{2}{*}{$\%$} & \multirow{2}{*}{ Mean } & \multirow{2}{*}{ Min } & \multirow{2}{*}{ Max } \\
\hline Range & Criteria & & & & & \\
\hline $15,00-26,25$ & Very bad & 0 & 0 & \multirow{4}{*}{37,6} & \multirow{4}{*}{30} & \multirow{4}{*}{49} \\
\hline $26,26-37,50$ & Bad & 12 & 51,9 & & & \\
\hline $37,51-48,75$ & Good & 10 & 43,8 & & & \\
\hline $48,76-60,00$ & Very good & 1 & 4,3 & & & \\
\hline
\end{tabular}


Based on Table 12, female students of class B showed perceptions on the mathematical physics e-module with very bad criteria about $0 \%$, bad criteria of $51.9 \%$ ( 12 out of 23 students), good criteria of $43.8 \%$ (10 out of 23 students), and very good criteria of $4.3 \%$ ( 1 in 23 students). Meanwhile, based on the perception scale, the data obtained is a mean score of 37.6 with a minimum score of 30 and a maximum score of 49 . These results indicate that the perception of female students of class $B$ towards the mathematical physics e-module has a negative category and is in bad criteria.

The analysis results of descriptive statistics on the perception of male students of class $B$ towards mathematical physics e-module using SPSS 22 can be seen in Table 13.

Table 13. Description of the perceptions of male students in class $B$

\begin{tabular}{|c|c|c|c|c|c|c|}
\hline \multicolumn{2}{|c|}{ Classification } & \multirow{2}{*}{ Total } & \multirow{2}{*}{$\%$} & \multirow{2}{*}{ Mean } & \multirow{2}{*}{ Min } & \multirow{2}{*}{ Max } \\
\hline Range & Criteria & & & & & \\
\hline $15,00-26,25$ & Very bad & 0 & 0 & \multirow{4}{*}{41,82} & \multirow{4}{*}{33} & \multirow{4}{*}{55} \\
\hline $26,26-37,50$ & Bad & 5 & 21,6 & & & \\
\hline $37,51-48,75$ & Good & 10 & 43,2 & & & \\
\hline $48,76-60,00$ & Very good & 2 & 8,6 & & & \\
\hline
\end{tabular}

Based on Table 13, male students of class B showed perceptions on the mathematical physics e-module with very bad criteria about $0 \%$, bad criteria of $5 \%$ ( 5 out of 17 students), good criteria of $43.2 \%$ ( 10 out of 17 students), and very good criteria of $8.6 \%$ ( 2 out of 17 students). Meanwhile, based on the perception scale, the data obtained is a mean score of 41.82 with a minimum score of 33 and a maximum score of 55 . These results indicate that the perception of male students of class $B$ towards the mathematical physics e-module has a positive category and is in good criteria.

After the descriptive statistical analysis is carried out, the next step is inferential analysis, namely the t-test. However, before conducting the $t$ test, a normality test and homogeneity test were carried out to see whether the research data were normal and homogeneous. The results of the data normality test using SPSS 22 can be seen in Table 14.

Table 14. SPSS Output Normality Test Results

\begin{tabular}{|c|c|c|}
\hline & Classification & Total \\
\hline $\mathrm{N}$ & & 17 \\
\hline \multirow{2}{*}{ Normal Parameters } & Mean & ,00 \\
\hline & Std. Deviation & 3,9819 \\
\hline Most Extreme & Absolute & ,090 \\
\hline \multirow[t]{2}{*}{ Difderences } & Positive & ,090 \\
\hline & Negatve &,- 072 \\
\hline \multicolumn{2}{|c|}{ Kolmogrov-Smimove Z } & ,090 \\
\hline \multicolumn{2}{|l|}{ Asymp. Sig. (2-tailed) } & ,200 \\
\hline
\end{tabular}

a. Test distribution is normal

From Table 14, the output of the SPSS normality test is K-S Z $=0.090$ with $p=0.200(p>0.05)$, which means the data is normally distributed. Furthermore, after the data is normally distributed, homogeneity test is carried out to determine whether there are similarities in several population variants. This test is carried out as a prerequisite in conducting the t-test. The results of the homogeneity test using SPSS 22 can be seen in Table 15.

Table 15. SPSS Output Homogeneity Test Results

\begin{tabular}{cccc}
\hline Levene Statistic & $\mathrm{df}_{1}$ & $\mathrm{df}_{2}$ & Sig. \\
\hline 3,094 & 1 & 38 &, 087 \\
\hline
\end{tabular}

From Table 15, the output of the SPSS homogeneity test is obtained, namely the value of sig. 0.087 , which means that $p>0.05$ is the same as $0.087>0.05$, so the variance of the two population groups (female and male) in this study is considered homogeneous. After knowing that the data is normal and homogeneous, then the t-test is carried out. The results of the $t$ test using SPSS 22 can be seen in Table 16. 
Momentum: Physics Education Journal, 5 (2), 2021, 218

Astalini Astalini, Darmaji Darmaji, Dwi Agus Kurniawan, Nadia Natalia Simamora

Table 16. Results of the SPSS t-test Output

\begin{tabular}{|c|c|c|c|}
\hline Group & $\mathrm{N}$ & Sig. & Sig. (2 tailed) \\
\hline Female & 23 & \multirow{2}{*}{0,087} & 0,020 \\
\hline Male & 17 & & 0,013 \\
\hline
\end{tabular}

From Table 16 obtained the output result of SPSS test $t$ i.e. sig value. 0.087 . This means a sig value $0.087>0.05$ which indicates that the variance of data between female and male students in class A is homogeneous or equal. Then, it is also obtained the value of Sig. ( 2 tailed) 0.020 and 0.013 . Sig value. ( 2 tailed) obtained between female and male students in class $A$ are different, but both value Sig. ( 2 tailed) indicates of 0.05 which means that $\mathrm{HO}$ is rejected and $\mathrm{Ha}$ is accepted. Thus, there is a noticeable difference between the perception of female and male students in class B towards the mathematical physics e-module.

Based on the results of descriptive statistical analysis of female and male students in the study, $51.9 \%$ ( 12 of 23 ) female students in class B have a perception in bad criteria, and $43.2 \%$ (10 of 17) male students in class B have a perception in good criteria. Based on the inferential analysis, it was found that the learning outcomes data were normal and homogeneous, and the results of the t-test on female and male students in class A showed the value of Sig. ( 2 tailed) of 0.020 and 0.013 . This means the value of Sig. ( 2 tailed) is smaller than 0.05 which means $\mathrm{HO}$ is rejected and $\mathrm{Ha}$ is accepted.

Meanwhile, statistical analysis shows that there are negative perceptions of female students and positive perceptions of male students in class B in using the mathematical physics e-module. The results of statistical analysis are strengthened by the results of inferential analysis, namely the test which shows that there is a striking difference between the perceptions of female and male students in class $A$ in the mathematical physics e-module which is indicated by the presence of a Sig score. (2 tails) 0.020 and 0.013 .

In class $B$, female students have negative perceptions which indicate that students have not been able to accept the use of e-modules as a digital learning media for mathematical physics while the male students have. The gender difference in Class B shows a significant difference in perception of the electronic module. This shows that gender differences affect student perceptions because student perceptions are one's perspective on an object, where one's perspective is also not always good and acceptable or positive, but there are also negative ones. However, gender differences are not a barrier to technological developments in education. Education must be able to monitor technological developments, one of its applications is the use of digital learning media such as electronic modules. Digital learning media makes learning more innovative which not only contains learning material but also contains elements of entertainment needed to increase motivation or interest in learning (Williamson et al., 2019).

Perception is an individual's assessment of an object or information. The perceptions given by students are used by lecturers to choose the learning media that will be used to make it easier for students to understand the learning material. Based on the overall perception of students, on average the e-module can help students understand mathematical physics material, although there are differences in perceptions of different genders where the perception of male students is better than female students.

Students' perceptions that vary are expected to refer to positive perceptions so that they show an improvement in better knowledge and easier learning process (Dessie \& Sewagegn, 2019; Leeniva, 2019; Syauqi et al., 2020). Positive perceptions of male students indicate that the use of e-modules in mathematical physics learning is very important to support understanding of learning materials. This result also shows that they think logically about education in the future which will be more advanced along with the development of technology. In contrast to the perception of female students who tend to show negative perceptions, this may be caused by learning mathematics and physics which they think are better using printed books and writing notes than using e-modules. However, the use of printed books has now turned into electronic books in the form of e-modules because they are considered more practical and flexible, and can be used anywhere and anytime. In addition to containing text, the e-module also contains images, audio, video and animation, as well as formative 
tests or quizzes that can make it easier for students to understand the learning material (Hermawan et al., 2018; Li et al., 2016; Patel et al., 2018; Rahmat et al., 2020; Sofyan et al., 2019). Thus, students can study mathematical physics material earlier than it should be and can study it anywhere and anytime.

Gender is one of the factors that influence the perception of each individual. In general, everyone has different perceptions that are formed through family, close environment, media and educational institutions in order to achieve the desired goals. (Ayvaz-tuncel \& Tuncel, 2019; Chaaban et al., 2021; Osadebe \& Osadebe, 2020). In the learning process, gender can be an influential factor (Fitriani et al., 2019; Suyatna et al., 2018). Females have a clearer way of thinking with more organized emotions than males (Xu \& Waniganayake, 2018). Females have a clearer way of thinking so that the perception given by female students towards the use of e-modules clearly states that the use of printed books is better than e-modules because the use of printed books has long been used and has become a habit in every study that the use of printed books is always applied. It is in contrast to the mindset of male students who prefer to study using e-modules because it is more flexible and less hassle because e-modules can be accessed via smartphones without having to carry thick and heavy printed books.

Mathematical physics is one of the compulsory subjects in the Physics department at all universities in Indonesia, including the Physics Education Study Program, FKIP Jambi University. Mathematical physics courses are very important to be studied and understood by every student because mathematical physics courses are the basis for continuing further courses in physics education such as Mechanics, Modern Physics, Thermodynamics, Basic Electronics, Electricity and Magnetism, Statistical Physics, Atomic and Nuclear Physics, Quantum Physics and Physics of Solids. In addition, the final ability expected from this course is that students are able to apply various basic forms of mathematics in analytically solving various simple physics problems. The Mathematical Physics material studied is the application of Mathematics in the case of Physics which includes matrix equations, addition and multiplication of matrices, matrix inverses, matrix operators, special matrices and many more. Matrices operation material is one of the most important material for students to understand so that students are able to explain concepts, analyze and apply matrix operations. As a physics education student who will become a teacher, it is very important for every student to understand mathematical physics material, one of which is matrix operations. This is because as a prospective teacher, each student must be able to understand the learning material before delivering the material to students. Therefore, e-modules become electronic-based media that can help physics education students understand mathematical physics material.

The use of e-modules can increase students' interest in learning mathematical physics. Students can learn mathematical physics practically through smartphones that can be accessed anywhere and anytime. By working on the questions in the e-module, it can improve students' understanding abilities. This study shows that each student has their own perception in the use of media as technological advances in the field of education. The student's perception is influenced by gender. As a result, his research can be a guide for further research. The next researcher can conduct research on student perceptions of the mathematical physics e-module on student interest and motivation and student learning outcomes based on gender differences. Also, the further researchers can conduct research on student perceptions in the use of mathematical physics e-modules on students' critical thinking skills.

\section{Conclusion}

Based on the results of the study, there were differences in students' perceptions toward the e-module. Student perceptions were obtained by reviewing students as a whole and by gender in each class. The overall perception of students (class A and class B) is positive with a Sig. value which shows that $\mathrm{HO}$ is rejected and $\mathrm{Ha}$ is accepted. There is also a significant difference between the perceptions of students in class $A$ and class $B$ towards the mathematical physics e-module based on gender. Class A shows a positive perception of the results of statistical analysis and Sig. value which 
shows that $\mathrm{HO}$ is rejected and $\mathrm{Ha}$ is accepted, which significantly different from the results of inferential analysis. However, class $B$ shows different results between the perceptions of female and male students. The results of the statistical description analysis shows that female students have a negative perception of the physics-mathematical e-module, while male students have a positive perception. This is supported by class B inferential analysis which shows the Sig. (2-tailed) value between female and male students are different but the Sig. (2-tailed) value of both states that there is a striking difference. So it can be concluded that students' perceptions toward mathematical phisics e-module can be seen as a whole or based on gender.

\section{Acknowledgment}

The researchers would like to thank the Physics Education Study Program in Universitas Jambi, the class of 2019 Physics Education students in Universitas Jambi, and all parties who have contributed in supporting and providing facilities for researchers to complete research so that this research can be conducted properly.

\section{References}

Abuhassna, H., \& Yahaya, N. (2018). Students' utilization of distance learning through an interventional online module based on moore transactional distance theory. EURASIA Journal of Mathematics, Science and Technology Education, 14(7), 3043-3052. https://doi.org/10.29333/ejmste/91606

Akar, H., \& Çelik, O. T. (2019). Organizational justice and cynicism: A mixed method study at schools. International Journal of Evaluation and Research in Education, 8(1), 189-200. https://doi.org/10.11591/ijere.v8i1.18296

Alkhateeb, M. A., \& Milhem, O. A. Q. B. (2020). Student's concepts of and approaches to learning and the relationships between them. Cakrawala Pendidikan, 39(3), 620-632. https://doi.org/10.21831/cp.v39i3.33277

Asrial, A., Syahrial, S., Maison, M., Kurniawan, D. A., \& Piyana, S. O. (2020). Ethnoconstructivism emodule to improve perception, interest, and motivation of students in class v elementary school. JPI (Jurnal Pendidikan Indonesia), 9(1), 30. https://doi.org/10.23887/jpiundiksha.v9i1.19222

Asrowi, A., Hadaya, A., \& Hanif, M. (2019). The impact of using the interactive e-book on students' learning outcomes. International Journal of Instruction, 12(2), 709-722. https://doi.org/10.29333/iji.2019.12245a

Ayvaz-tuncel, Z., \& Tuncel, i. (2019). Good teacher perceptions of students attending the pedagogical formation certificate program. International Journal of Evaluation and Research in Education (IJERE), 8(1), 165-172. https://doi.org/10.11591/ijere.v8i1.17093

Barr, M., \& Jackson, L. H. (2018). Enhancing delivery and assessment: A case study in module redesign for improved transition into higher education. Journal of Political Science Education, 14(3), 390-399. https://doi.org/10.1080/15512169.2017.1415812

Berek, F. X., Sutopo, S., \& Munzil, M. (2016). Enhancement of junior high school students' concept comprehension in hydrostatic pressure and Archimedes law concepts by predict-observeexplain strategy. Jurnal Pendidikan IPA Indonesia, 5(2), 230-238. https://doi.org/10.15294/jpii.v5i2.6038

Bhagat, K. K., \& Chang, C. (2017). A cross-cultural comparison on students' perceptions towards online learning. EURASIA Journal of Mathematics, Science and Technology Education, 14(3), 987-995. https://doi.org/10.12973/ejmste/81151

Bice, M. R., Ball, J. W., Hollman, A., \& Adkins, M. (2019). Health technology use: implications for physical activity behaviors among college students. International Journal of Kinesiology in Higher Education, 3(1), 23-34. https://doi.org/10.1080/24711616.2018.1516524 
Billman, A., Harding, A., \& Engelbrecht, J. (2018). Does the chalkboard still hold its own against modern technology in teaching mathematics? A case study. International Journal of Mathematical Education in Science and Technology, 49(6), 809-823. https://doi.org/10.1080/0020739X.2018.1431852

Caia, J., Thornton, H. R., Kelly, V. G., Scott, T. J., Halson, S. L., Cupples, B., \& Driller, M. W. (2018). Does self-perceived sleep reflect sleep estimated via activity monitors in professional rugby league athletes? Journal of Sports Sciences, 36(13), 1492-1496. https://doi.org/10.1080/02640414.2017.1398885

Chaaban, Y., Qadhi, S., \& Du, X. (2021). Student teachers' perceptions of factors influencing learner agency working in teams in a STEAM-based course. Eurasia Journal of Mathematics, Science and Technology Education, 17(7), em1980. https://doi.org/10.29333/ejmste/10978

Chiu, M. (2018). Effects of early numeracy activities on mathematics achievement and affect: Parental value and child gender conditions and socioeconomic status mediation. EURASIA Journal of Mathematics, Science and Technology Education, 14(12), 1-16. https://doi.org/10.29333/ejmste/97191

Chongo, S., Osman, K., \& Nayan, N. A. (2021). Impact of the plugged-in and unplugged chemistry computational thinking modules on achievement in chemistry. Eurasia Journal of Mathematics, Science and Technology Education, 17(4), em1953. https://doi.org/10.29333/ejmste/10789

Cohen, L., Manion, L., \& Morrison, K. (2007). Research methods in education (6th ed.). Routledge.

Dalkilic, F., Cabuk, U. C., Arikan, E., \& Gurkan, A. (2017). An analysis of the positioning accuracy of iBeacon technology in indoor environments. 2017 International Conference on Computer Science and Engineering (UBMK), 549-553. https://doi.org/10.1109/UBMK.2017.8093459

Darmaji, D., Astalini, A., Kurniawan, D. A., Parasdila, H., Irdianti, I., Susbiyanto, S., Kuswanto, K., \& Ikhlas, M. (2019). E-module based problem solving in basic physics practicum for science process skills. International Journal of Online and Biomedical Engineering (IJOE), 15(15), 4. https://doi.org/10.3991/ijoe.v15i15.10942

Darmaji, D., Kurniawan, D. A., Astalini, A., \& Nasih, N. R. (2019). Persepsi mahasiswa pada penuntun praktikum fisika dasar II berbasis mobile learning. Jurnal Pendidikan: Teori, Penelitian, Dan Pengembangan, 4(4), 516-523. https://doi.org/10.17977/jptpp.v4i4.12345

Darmaji, D., Kurniawan, D. A., Astalini, A., Perdana, R., Kuswanto, K., \& Ikhlas, M. (2020). Do a science process skills affect on critical thinking in science? Differences in urban and rural. International Journal of Evaluation and Research in Education (IJERE), 9(4), 874. https://doi.org/10.11591/ijere.v9i4.20687

Darmaji, D., Kurniawan, D. A., Astalini, A., Winda, F. R., Heldalia, H., \& Kartina, L. (2020). The correlation between student perceptions of the use of e-modules with students' basic science process skills. JPI (Jurnal Pendidikan Indonesia), 9(4), 719. https://doi.org/10.23887/jpiundiksha.v9i4.28310

Darmaji, D., Kurniawan, D. A., \& Irdianti, I. (2019). Physics education students' science process skills. International Journal of Evaluation and Research in Education, 8(2), 293-298. https://doi.org/10.11591/ijere.v8i2.28646

Dessie, A. A., \& Sewagegn, A. A. (2019). Moving beyond a sign of judgment: primary school teachers' perception and practice of feedback. International Journal of Instruction, 12(2), 51-66. https://doi.org/10.29333/iji.2019.1224a

Dharma, L., Agusti, R., \& Kurnia, P. (2016). Pengaruh gender, pemahaman perpajakan dan religiusitas terhadap persepsi penggelapan pajak. Jurnal Online Mahasiswa (JOM) Bidang Ilmu Ekonomi, 3(1), 1565-1578. https://jom.unri.ac.id/index.php/JOMFEKON/article/view/11764

Dwi Lestari, H., \& Putu Parmiti, D. P. P. (2020). Pengembangan e-modul IPA bermuatan tes online untuk meningkatkan hasil belajar. Journal of Education Technology, 4(1), 73.

https://doi.org/10.23887/jet.v4i1.24095 
Elmendorf, D. C., \& Song, L. (2015). Developing indicators for a classroom observation tool on pedagogy and technology integration: A Delphi study. Computers in the Schools, 32(1), 1-19. https://doi.org/10.1080/07380569.2014.967620

Fitriani, H., Asy'ari, M., Zubaidah, S., \& Mahanal, S. (2019). Exploring the prospective teachers' critical thinking and critical analysis skills. Jurnal Pendidikan IPA Indonesia, 8(3), 379-390. https://doi.org/10.15294/jpii.v8i3.19434

Fortner, S. K., Scherer, H. H., \& Murphy, M. A. (2016). Engaging undergraduates in soil sustainability decision-making through an integrate module. Journal of Geoscience Education, 64(4), 259-269. https://doi.org/10.5408/15-106.1

$\mathrm{Ge}, \mathrm{Z}$. (2021). Does mismatch between learning media preference and received learning media bring a negative impact on Academic performance? An experiment with e-learners. Interactive Learning Environments, 29(5), 790-806. https://doi.org/10.1080/10494820.2019.1612449

Goh, C. C. M., \& Hu, G. (2014). Exploring the relationship between metacognitive awareness and listening performance with questionnaire data. Language Awareness, 23(3), 255-274. https://doi.org/10.1080/09658416.2013.769558

Gunawan, G., Harjono, A., Hermansyah, H., \& Herayanti, L. (2019). Guided inquiry model through virtual laboratory to enhance students' science process skills on heat concept. Jurnal Cakrawala Pendidikan, 38(2), 259-268. https://doi.org/10.21831/cp.v38i2.23345

Hammer, H. L., \& Habib, L. (2016). A quantitative analysis of uncertainty in the grading of written exams in mathematics and physics. Eurasia Journal of Mathematics, Science and Technology Education, 12(4), 975-989. https://doi.org/10.12973/eurasia.2016.1240a

Hermawan, H., Samsuri, S., Kurniawati, D. P., Sofyaningsih, V., \& Prasetyo, D. (2018). The use of the controversial public issue learning model with videos and a macromedia flash player on Civic Education. Psychology, Evaluation, and Technology in Educational Research, 1(1), 19-30. https://doi.org/10.33292/petier.v1i1.2

Hodis, F. A., \& Hancock, G. R. (2016). Introduction to the special issue: Advances in quantitative methods to further research in education and educational psychology. Educational Psychologist, 51(3-4), 301-304. https://doi.org/10.1080/00461520.2016.1208750

Holliday, J., Hennebry, J., \& Gammage, S. (2019). Achieving the sustainable development goals: surfacing the role for a gender analytic of migration. Journal of Ethnic and Migration Studies, 45(14), 2551-2565. https://doi.org/10.1080/1369183X.2018.1456720

Holmes, N. G., Kumar, D., \& Bonn, D. A. (2017). Toolboxes and handing students a hammer: The effects of cueing and instruction on getting students to think critically. Physical Review Physics Education Research, 13(1), 010116. https://doi.org/10.1103/PhysRevPhysEducRes.13.010116

Hu, Y.-H., Xing, J., \& Tu, L.-P. (2018). The effect of a problem-oriented teaching method on university mathematics learning. EURASIA Journal of Mathematics, Science and Technology Education, 14(5), 1695-1703. https://doi.org/10.29333/ejmste/85108

Ibrahim, Z., Alias, N., \& Nordin, A. B. (2016). Needs analysis for graphic design learning module based on technology \& learning styles of deaf students. Cogent Education, 23(1), 1-14. https://doi.org/10.1080/2331186X.2016.1178364

Ikeda, R., Kikuchi, T., Miyazaki, H., Hidaka, H., Kawase, T., Katori, Y., \& Kobayashi, T. (2018). The efficacy of the Eustachian Tube Dysfunction Questionnaire (ETDQ-7) for patulous Eustachian tube patient. Acta Oto-Laryngologica, 138(1), 6-9. https://doi.org/10.1080/00016489.2017.1366053

Kim, M. K., Lee, J. Y., Yang, H., Lee, J., Jang, J. N., \& Kim, S. J. (2019). Analysis of elementary school teachers' perceptions of mathematics-focused STEAM education in Korea. EURASIA Journal of Mathematics, Science and Technology Education, 15(9).

https://doi.org/10.29333/ejmste/108482 
Koutiva, I., Gerakopoulou, P., Makropoulos, C., \& Vernardakis, C. (2017). Exploration of domestic water demand attitudes using qualitative and quantitative social research methods. Urban Water Journal, 14(3), 307-314. https://doi.org/10.1080/1573062X.2015.1135968

Laurens, T., Batlolona, F. A., Batlolona, J. R., \& Leasa, M. (2017). How does realistic mathematics education (RME) improve students' mathematics cognitive achievement? EURASIA Journal of Mathematics, Science and Technology Education, 14(2), 569-578. https://doi.org/10.12973/ejmste/76959

Leeniva, P. (2019). Comparative analysis of auditory perception based on educational background differences. International Journal of Instruction, 12(2), 227-242. https://doi.org/10.29333/iji.2019.12215a

Leinonen, T., Keune, A., Veermans, M., \& Toikkanen, T. (2016). Mobile apps for reflection in learning: A design research in K-12 education. British Journal of Educational Technology, 47(1), 184-202. https://doi.org/10.1111/bjet.12224

Li, W., Cashell, A., Jaffray, D. A., \& Moseley, D. (2016). Development and Implementation of an Electronic Learning Module for Volumetric Image-Guided Radiation Therapy. Journal of Medical Imaging and Radiation Sciences, 47(1), 43-48. https://doi.org/10.1016/j.jmir.2015.12.001

Liu, I. F., \& Young, S. S. C. (2017). An exploration of participative motivations in a community-based online English extensive reading contest with respect to gender difference. Interactive Learning Environments, 25(1), 48-61. https://doi.org/doi:10.1080/10494820.2015.1090457

Lupi, J. B., Carvalho de Abreu, D. C., Ferreira, M. C., Oliveira, R. D. R. de, \& Chaves, T. C. (2017). Brazilian Portuguese version of the Revised Fibromyalgia Impact Questionnaire (FIQR-Br): crosscultural validation, reliability, and construct and structural validation. Disability and Rehabilitation, 39(16), 1650-1663. https://doi.org/10.1080/09638288.2016.1207106

Marquezin, M. C. S., Pedroni-Pereira, A., Araujo, D. S., Rosar, J. V., Barbosa, T. S., \& Castelo, P. M. (2016). Descriptive analysis of the masticatory and salivary functions and gustatory sensitivity in healthy children. Acta Odontologica Scandinavica, 74(6), 443-448. https://doi.org/10.1080/00016357.2016.1191085

Mcnamara, D. S., \& Shapiro, A. M. (2015). Multimedia and hypermedia solutions for promoting metacognitive engagement, coherence, and learning. Journal of Educational Computing Research, 33(1), 1-29.

$\mathrm{Ng}, \mathrm{W}$. (2019). A partnership-designed online module on climate science: Impact on year 10 teachers and students. Eurasia Journal of Mathematics, Science and Technology Education, 15(2). https://doi.org/10.29333/ejmste/100638

Ningtyas, R. N., Suarsini, E., \& Amin, M. (2019). Eksplorasi kebutuhan bahan ajar mikrobiologi untuk mahasiswa. Jurnal Pendidikan: Teori, Penelitian, Dan Pengembangan, 4(9), 1185-1189. https://doi.org/10.17977/jptpp.v4i9.12703

Osadebe, P. U., \& Osadebe, J. F. (2020). Undergraduate bus iness education students ' perception on information and communication technology use in teaching and learning. International Journal of Evaluation and Research in Education (IJERE), 9(2), 359-363. https://doi.org/10.11591/ijere.v9i2.20326

Oyedeji, S. O. (2017). The effects of students' motivational factors on their attitudes toward mathematics. International Journal of Evaluation and Research in Education (IJERE), 6(4), 277. https://doi.org/10.11591/ijere.v6i4.10770

Park, B., Flowerday, T., \& Brünken, R. (2015). Cognitive and affective effects of seductive details in multimedia learning. Computers in Human Behavior, 44(44), 267-278. https://doi.org/10.1016/j.chb.2014.10.061

Pastore, S. (2017). Research designs and methods in self-assessment studies: a content analysis. International Journal of Evaluation and Research in Education (IJERE), 6(4), 257. https://doi.org/10.11591/ijere.v6i4.8921 
Patel, S. R., Margolies, P. J., Covell, N. H., Lipscomb, C., \& Dixon, L. B. (2018). Using instructional design, analyze, design, develop, implement, and evaluate, to develop e-learning modules to disseminate supported employment for community behavioral health treatment programs in New York State. Frontiers in Public Health, 6. https://doi.org/10.3389/fpubh.2018.00113

Ping, I. L. L., \& Osman, K. (2019). Laboratory-modified argument driven inquiry (Lab-Madi) module: Content validity process. Jurnal Pendidikan IPA Indonesia, 8(1), 129-140. https://doi.org/10.15294/jpii.v8i1.16867

Prani, A. I. E., Parno, P., \& Hidayat, A. (2018). Keterampilan berpikir kritis pada Bounded Inquiry Lab: analisis kuantitatif dan kualitatif. Momentum: Physics Education Journal, 2(1), 29-38. https://doi.org/10.21067/mpej.v1i1.2217

Purnami, A. S., Mulyoto, M., \& Winoto, B. (2020). Android-based shopping skill for mentally-disable student. Journal of Education and Learning (EduLearn), 14(3), 411-415. https://doi.org/10.11591/edulearn.v14i3.16110

Qi, A. (2018). A study of the effect of implementing intellectual property education with digital teaching on learning motivation and achievements. Eurasia Journal of Mathematics, Science and Technology Education, 14(6), 2445-2452. https://doi.org/10.29333/ejmste/89498

Quintela-del-Río, A., \& Francisco-Fernández, M. (2017). Excel templates: A helpful tool for teaching statistics. The American Statistician, 71(4), 317-325. https://doi.org/10.1080/00031305.2016.1186115

Qureshi, M. N., Kadilar, C., Amin, M. N. U., \& Hanif, M. (2018). Rare and clustered population estimation using the adaptive cluster sampling with some robust measures. Journal of Statistical Computation and Simulation, 88(14), 2761-2774. https://doi.org/10.1080/00949655.2018.1486842

Rahmat, M. R., Arip, A. G., \& Nur, S. H. (2020). Implementation of problem- based learning model assisted by e-modules on students' critical thinking ability. JPI (Jurnal Pendidikan Indonesia), 9(3), 339. https://doi.org/10.23887/jpi-undiksha.v9i3.22410

Rahmatika, H., Lestari, S. R., \& Sari, M. S. (2020). Preliminary study of PBL-based e-module development based on research results to improve students' critical thinking skills and cognitive learning outcomes. AIP Conference Proceedings, 2330(4), 565-575. https://doi.org/10.1063/5.0043319

Rezeki, S., Andrian, D., \& Safitri, Y. (2021). Mathematics and cultures: a new concept in maintaining cultures through the development of learning devices. International Journal of Instruction, 14(3), 375-392. https://doi.org/10.29333/iji.2021.14322a

Rintakorpi, K., \& Reunamo, J. (2017). Pedagogical documentation and its relation to everyday activities in early years. Early Child Development and Care, 187(11), 1611-1622. https://doi.org/10.1080/03004430.2016.1178637

Rote, A. E. (2017). Physical activity intervention using Fitbits in an introductory college health course. Health Education Journal, 76(6), 337-348.

Rusydiyah, E. F., Purwati, E., \& Prabowo, A. (2020). How to use digital literacy as a learning resource for teacher candidates in Indonesia. Cakrawala Pendidikan, 39(2), 305-318. https://doi.org/10.21831/cp.v39i2.30551

Septiani, A. N. S. I., Rejekiningsih, T., Triyanto, \& Rusnaini. (2020). Development of interactive multimedia learning courseware to strengthen students' character. European Journal of Educational Research, 9(3), 1267-1279. https://doi.org/10.12973/eu-jer.9.3.1267

Shang, H.-F. (2017). Exploring metacognitive strategies and hypermedia annotations on foreign language reading. Interactive Learning Environments, 25(5), 610-623. https://doi.org/10.1080/10494820.2016.1171787

Shang, H. L. (2015). Resampling techniques for estimating the distribution of descriptive statistics of 
functional data. Communications in Statistics - Simulation and Computation, 44(3), 614-635. https://doi.org/10.1080/03610918.2013.788703

Simpson, G. K., \& Lord, B. (2015). Enhancing the reporting of quantitative research methods in Australian social work. Australian Social Work, 68(3), 375-383. https://doi.org/10.1080/0312407X.2015.1035662

Singh, S. (2003). Advanced samplin theory with applications. Kluwer Academic.

Siswono, H. (2017). Analisis pengaruh keterampilan proses sains terhadap penguasaan konsep fisika siswa. Momentum: Physics Education Journal, 1(2), 83. https://doi.org/10.21067/mpej.v1i2.1967

Sofyan, H., Anggraeni, E., \& Saadiah, J. (2019). Development of e-modules based on local wisdom in central learning model at kindergartens in Jambi City. European Journal of Educational Research, 8(4), 1137-1143. https://doi.org/10.12973/eu-jer.8.4.1137

Sopacua, J., Fadli, M. R., \& Rochmat, S. (2020). The history learning module integrated character values. Journal of Education and Learning (EduLearn), 14(3), 463-472. https://doi.org/10.11591/edulearn.v14i3.16139

Stebner, F., Kühl, T., Höffler, T. N., Wirth, J., \& Ayres, P. (2017). The role of process information in narrations while learning with animations and static pictures. Computers \& Education, 104, $34-$ 48. https://doi.org/10.1016/j.compedu.2016.11.001

Stojanović, D., Bogdanović, Z., Petrović, L., Mitrović, S., \& Labus, A. (2020). Empowering learning process in secondary education using pervasive technologies. Interactive Learning Environments, 1-14. https://doi.org/10.1080/10494820.2020.1806886

Sumual, M. Z. I., \& Ali, M. (2017). Evaluation of primary school teachers' competence in implementing 2013 curriculum: A study in Tomohon City. Journal of Education and Learning (EduLearn), 11(3), 343-350. https://doi.org/10.11591/edulearn.v11i3.6429

Suryanti, S., \& Arifani, Y. (2021). The relationship between blended mathematics professional training and teachers' creativity and effectiveness. International Journal of Instruction, 14(2), 139-154. https://doi.org/10.29333/iji.2021.1429a

Suyatna, A., Maulina, H., Rakhmawati, I., \& Khasanah, R. A. N. (2018). Electronic versus printed book: comparison study on the effectivity of senior high school physics book. Jurnal Pendidikan IPA Indonesia, 7(4), 391-398. https://doi.org/10.15294/jpii.v7i4.14437

Syauqi, K., Munadi, S., \& Triyono, M. B. (2020). Students ' perceptions toward vocational education on online learning during the COVID-19 pandemic. International Journal of Evaluation and Research in Education (IJERE), 9(4), 881-886. https://doi.org/10.11591/ijere.v9i4.20766

Tiruneh, D. T., De Cock, M., Weldeslassie, A. G., Elen, J., \& Janssen, R. (2017). Measuring critical thinking in physics: development and validation of a critical thinking test in electricity and magnetism. International Journal of Science and Mathematics Education, 15(4), 663-682. https://doi.org/10.1007/s10763-016-9723-0

Tiruneh, D. T., Weldeslassie, A. G., Kassa, A., Tefera, Z., De Cock, M., \& Elen, J. (2016). Systematic design of a learning environment for domain-specific and domain-general critical thinking skills. Educational Technology Research and Development, 64(3), 481-505. https://doi.org/10.1007/s11423-015-9417-2

Tölle, T. R., Baron, R., de Bock, E., Junor, R., Dias Barbosa, C., Marshall, S. F., Arnould, B., \& Freynhagen, R. (2019). painPREDICT: first interim data from the development of a new patientreported pain questionnaire to predict treatment response using sensory symptom profiles. Current Medical Research and Opinion, 35(7), 1177-1185. https://doi.org/10.1080/03007995.2018.1562687

Torbjörnsson, E., Olivecrona, C., \& Sonden, A. (2018). An interprofessional initiative aimed at creating a common learning resource for the operating room ward. Journal of Interprofessional Care, 


\section{2(4), 501-504. https://doi.org/10.1080/13561820.2018.1435516}

Tristanti, L. B., \& Hidayati, W. S. (2020). The implementation of cooperative learning type team assisted individualisation for teaching 3D geometry. Journal of Education and Learning (EduLearn), 14(2), 279-288. https://doi.org/10.11591/edulearn.v14i2.11139

Vartiainen, H., Leinonen, T., \& Nissinen, S. (2019). Connected learning with media tools in kindergarten: an illustrative case. Educational Media International, 56(3), 233-249. https://doi.org/10.1080/09523987.2019.1669877

Vincent, K., \& Thompson, S. (2017). Estimating population size with link-tracing sampling. Journal of the American Statistical Association, 112(519), 1286-1295. https://doi.org/10.1080/01621459.2016.1212712

Wang, H., \& Chang, T. C. (2018). A new mental experience quantification and emotion prediction model for E-learning users. Eurasia Journal of Mathematics, Science and Technology Education, 14(6), 2623-2638. https://doi.org/10.29333/ejmste/90259

Wartono, W., Hudha, M. N., \& Batlolona, J. R. (2017). How are the physics critical thinking skills of the students taught by using inquiry-discovery through empirical and theorethical overview? EURASIA Journal of Mathematics, Science and Technology Education, 14(2), 691-697. https://doi.org/10.12973/ejmste/80632

Wati, M., Misbah, M., Haryandi, S., \& Dewantara, D. (2020). The effectiveness of local wisdom-based static fluid modules in the wetlands environment. Momentum: Physics Education Journal, 4(2), 102-108. https://doi.org/10.21067/mpej.v4i2.4769

West, S. E. (2015). Evaluation, or just data collection? An exploration of the evaluation practice of selected UK environmental educators. Journal of Environmental Education, 46(1), 41-55. https://doi.org/10.1080/00958964.2014.973351

Widoyoko, E. P. (2012). Teknik penyusunan instrumen penelitian. Pustaka Pelajar.

Williamson, B., Potter, J., \& Eynon, R. (2019). New research problems and agendas in learning, media and technology: the editors' wishlist. Learning, Media and Technology, 44(2), 87-91. https://doi.org/10.1080/17439884.2019.1614953

Wu, H., \& Leung, S.-O. (2017). Can Likert scales be treated as interval scales? -A simulation study. Journal of Social Service Research, 43(4), 527-532. https://doi.org/10.1080/01488376.2017.1329775

Xiao, C., \& Hong, D. (2017). Gender differences in concerns for the environment among the Chinese public: An update. Society \& Natural Resources, 30(6), 782-788. https://doi.org/10.1080/08941920.2016.1238986

Xu, J., Li, B. K., \& Luo, S. M. (2018). Practice and exploration on teaching reform of engineering project management course in universities based on bim simulation technology. Eurasia Journal of Mathematics, Science and Technology Education, 14(5), 1827-1835. https://doi.org/10.29333/ejmste/85417

Xu, Y., \& Waniganayake, M. (2018). An exploratory study of gender and male teachers in early childhood education and care centres in China. Compare: A Journal of Comparative and International Education, 48(4), 518-534. https://doi.org/10.1080/03057925.2017.1318355

Yalcın, S. (2017). Teacher behaviours explaining Turkish and Dutch students' mathematic achievements. International Journal of Evaluation and Research in Education (IJERE), 6(2), 174. https://doi.org/10.11591/ijere.v6i2.7596

Yasa, A. D., Chrisyarani, D. D., Akbar, S., \& Mudiono, A. (2018). E-module based on ncesoft book maker for primary school student. International Journal of Engineering \& Technology, 7(3.4), 286-289. https://doi.org/10.14419/ijet.v7i3.4.19973 